\title{
Fulminant type 1 diabetes as an important exception to the new diagnostic criteria using $\mathrm{HbA}_{1 \mathrm{c}}$-response to the International Expert Committee
}

\author{
A. Imagawa - T. Hanafusa
}

Received: 19 June 2009 / Accepted: 7 August 2009/Published online: 1 September 2009

(C) Springer-Verlag 2009

Keywords Criteria $\cdot$ Diagnosis $\cdot$ Fulminant $\cdot$ Idiopathic

\section{Abbreviation \\ JDS Japan Diabetes Society}

To the Editor: Taking into consideration that chronic hyperglycaemia sufficient to cause diabetes-specific complications is the defining feature of diabetes, an International Expert Committee (with members appointed by the American Diabetes Association, the European Association for the Study of Diabetes and the International Diabetes Federation) recommended a cut-off point for $\mathrm{HbA}_{1 \mathrm{c}}$ of $6.5 \%$ for the diagnosis of diabetes [1]. The Committee's report highlighted the limitation of $\mathrm{HbA}_{1 \mathrm{c}}$ in patients with rapidly evolving type 1 diabetes, where the $\mathrm{HbA}_{1 \mathrm{c}}$ level will not have had time to 'catch up' with the acute elevation in glucose levels. In this situation, diabetes should be diagnosed from typical symptoms and random blood glucose levels $>11.1 \mathrm{mmol} / \mathrm{l}(200 \mathrm{mg} / \mathrm{dl})$ despite a nondiagnostic $\mathrm{HbA}_{1 \mathrm{c}}$ level. In another section of the report, the Committee notes most cases of type 1 diabetes, particularly in children and adolescents, are diagnosed by the classical

\footnotetext{
A. Imagawa

Department of Metabolic Medicine,

Graduate School of Medicine,

Osaka University, Suita, Japan

T. Hanafusa

First Department of Internal Medicine,

Osaka Medical College, Takatsuki, Japan

A. Imagawa $(\square)$

2-2-B5 Yamadaoka,

Suita 565-0871, Japan

e-mail: aimagawa@endmet.med.osaka-u.ac.jp
}

symptoms of polyuria, polydipsia, polyphagia, unexplained weight loss and a random blood glucose $>11.1 \mathrm{mmol} / 1$.

We have defined a model of rapidly evolving type 1 diabetes (fulminant type 1 diabetes) that is characterised by an absence of islet autoantibody and a markedly rapid onset $[2,3]$. This is certainly an important subtype within diabetes but does not meet the new diagnostic criteria using $\mathrm{HbA}_{1 \mathrm{c}}$. To confirm this, we determined the prevalence of patients with fulminant type 1 diabetes who had $\mathrm{HbA}_{1 \mathrm{c}} \leq 6.1 \%$ at the onset of disease. According to the formula of the National Glycohemoglobin Standardization Program value ' $\mathrm{HbA}_{1 \mathrm{c}} \geq 6.5 \%$ ' in the USA is equivalent to ' $\mathrm{HbA} \mathrm{Ac}_{1 \mathrm{c}} \geq 6.2 \%$ ' in Japan (US value [\%] = Japan Diabetes Society [JDS] value $[\%]+0.3 \%$, determined by using Japanese standard reference material for JDS Lot $2 \mathrm{HbA}_{1 \mathrm{c}}$ ) [4]. Ninety-nine patients who suffered from fulminant type 1 diabetes after March 2001 were selected from a nationwide cohort of fulminant type 1 diabetes [5]. We selected the patients from March 2001 onwards because until that time the measurement of $\mathrm{HbA}_{1 \mathrm{c}}$ had not been standardised by using JDS Lot 2 . As a result, the prevalence of patients who had $\mathrm{HbA}_{1 \mathrm{c}}$ $\leq 6.1 \%$ at disease onset was $55.6 \%$ (55/99), while all had a blood glucose level $>11.2 \mathrm{mmol} / \mathrm{l}(200 \mathrm{mg} / \mathrm{dl})$ and their average blood glucose level was $41.5 \mathrm{mmol} / \mathrm{l}(747 \mathrm{mg} / \mathrm{dl})$. However, the average $\mathrm{HbA}_{1 \mathrm{c}}$ level was $12.2 \%$ at onset; this accords with the new criteria in classical type $1 \mathrm{~A}$ diabetes in our previous report, suggesting chronic hyperglycaemia due to continuous beta cell loss [3]. Fulminant type 1 diabetes is not uncommon in the Asian population, in which it accounts for approximately $20 \%$ of ketosis-onset type 1 diabetes $[3,6]$; it has also been reported in a white population [7]. In addition, it is noteworthy that almost all patients with fulminant type 1 diabetes are not children or adolescents, but adults [5]. At the onset of fulminant type 1 diabetes, patients often complain of non-specific symptoms, 
such as general fatigue and loss of consciousness, and they sometimes do not have classic symptoms of hyperglycaemia such as polyuria, polydipsia and polyphagia. This implies that sometimes the diagnosis of diabetic ketoacidosis cannot be made at onset of fulminant type 1 diabetes, which may well result in death.

From this evidence, fulminant type 1 diabetes should be highlighted as an important exception to the new diagnostic criteria using $\mathrm{HbA}_{1 \mathrm{c}}$.

Acknowledgement This study was supported by the Japan Diabetes Society.

\section{References}

1. The International Expert Committee (2009) International Expert Committee report on the role of the A1C assay in the diagnosis of diabetes. Diabetes Care 32:1327-1334
2. Imagawa A, Hanafusa T, Miyagawa J, Matsuzawa Y, for the Osaka IDDM Study Group (2000) A novel subtype of type 1 diabetes mellitus characterized by a rapid onset and an absence of diabetesrelated antibodies. N Engl J Med 342:301-307

3. Hanafusa T, Imagawa A (2007) Fulminant type 1 diabetes: a novel clinical entity requiring special attention by all medical practitioners. Nat Clin Pract Endocrinol Metab 3:36-45

4. Tominaga M, Makino H, Yoshino G et al (2005) Japanese standard reference material for JDS Lot 2 haemoglobin A1c. I: Comparison of Japan Diabetes Society-assigned values to those obtained by the Japanese and USA domestic standardization programmes and by the International Federation of Clinical Chemistry reference laboratories. Ann Clin Biochem. 42:41-46

5. Imagawa A, Hanafusa $T$, Iwahashi $\mathrm{H}$ et al (2008) Uniformity in clinical and HLA-DR status regardless of age and gender within fulminant type 1 diabetes. Diabetes Res Clin Pract 82:233237

6. Cho YM, Kim JT, Ko KS et al (2007) Fulminant type 1 diabetes in Korea: high prevalence among patients with adult-onset type 1 diabetes. Diabetologia 50:2276-2279

7. Moreau C, Drui D, Arnault-Ouary G, Charbonnel B, Chaillous L, Cariou B (2008) Fulminant type 1 diabetes in Caucasians: a report of three cases. Diabetes Metab 34:529-532 